\title{
Effect of a multi-ingredient supplement on intermittent sprint performance, fatigue perception, muscle damage and immunosuppression in recreational athletes
}

\author{
Fernando Naclerio ${ }^{1 *}$, Eneko Larumbe-Zabala ${ }^{2}$, Robert Cooper ${ }^{1}$, Allgrove Judith ${ }^{3}$, Ahmad Alkhatib ${ }^{4}$, \\ Daniel Baddeley-White ${ }^{1}$, Sergio Garcia ${ }^{1}$, Tobia Zanotto ${ }^{1}$
}

From The Eleventh International Society of Sports Nutrition (ISSN) Conference and Expo

Clearwater Beach, FL, USA. 20-21 June 2014

\section{Background}

It has been suggested that carbohydrate-protein based multi-ingredient supplements may attenuate exercise induced muscle damage (EIMD) and immunosuppression. This study investigates the effects of a commercially available carbohydrate-protein supplement (MTN) enriched with L-glutamine, L-carnitine-L-tartrate compared to carbohydrate alone $(\mathrm{CHO})$ or placebo (PL), on sprint performance, muscle damage, immunosuppression markers and recovery from an intermittent exercise bout.

\section{Methods}

On three occasions, in a counterbalanced order, 16 recreationally trained males volunteered to ingest a multi-ingredient supplement, a carbohydrate supplement or placebo before, during and immediately after a $90 \mathrm{~min}$ intermittent repeated sprint test (IRS). Measurements included total sprint time and the rate of perceived exertion (RPE) expressed along the IRS. In addition $15 \mathrm{~m}$ sprint, creatine kinase, myoglobin, interleukine-6, Salivary $\alpha$ amylase; Neutrophil; Lymphocytes and Monocyte were assessed pre, immediately post, $1 \mathrm{~h}$ and $24 \mathrm{~h}$ after exercise. Consent to publish the results was obtained from all participants.

\section{Results}

Total sprint times were not different between conditions. RPE increased during the IRS for all conditions, however

\footnotetext{
* Correspondence: f.j.naclerio@gre.ac.uk

'Centre for Sport Science and Human Performance, School of Science, University of Greenwich, United Kingdom

Full list of author information is available at the end of the article
}

MTN showed a significant $(\mathrm{p}<0.001)$ lower value at the end $(15.9 \pm 1.4)$ compared to PL $(17.8 \pm 1.4)$ but not with respect to $\mathrm{CHO}(17.0 \pm 1.9) .15 \mathrm{~m}$ sprint time was reduced $(\mathrm{p}<0.05)$ at post, $1 \mathrm{hr}$ and $24 \mathrm{hr}$ compared to pre with no differences between conditions ( $p>0.05)$. Myoglobin increased $(\mathrm{p}<0.05)$ in all three conditions at post, and $1 \mathrm{hr}$ compared to pre, showing lower values at $1 \mathrm{hr}(\mathrm{p}<0.05)$ for the $\mathrm{CHO}$ and MTN compared to PL $\left(241.8 \pm 142.6 \mathrm{ng} \mathrm{ml}^{-1}\right.$ and $265.4 \pm 187.8 \mathrm{ng} \mathrm{ml}^{-1}$ vs. $518.6 \pm 255.2 \mathrm{ng} \mathrm{ml}^{-1}$ respectively). Interleukin- 6 was significantly increased at post and $1 \mathrm{~h}$ compared to pre $(\mathrm{p}<0.05)$ being significantly higher for MTN at post (5.2pg. $\left.\mathrm{ml}^{-1}\right)$ and $24 \mathrm{hr}\left(2.4 \mathrm{pg} \cdot \mathrm{ml}^{-1}\right)$ respect to $\mathrm{CHO}\left(4.5 \pm 2.1\right.$ and $\left.1.9 \pm 2.5 \mathrm{pg} . \mathrm{ml}^{-1}\right)$ but not respect to PL $\left(4.9 \pm 2.4\right.$ and $1.8 \pm 2.4$ pg.ml $\left.{ }^{-1}\right)$. Creatine kinase peaks at $24 \mathrm{hr}$ for the three conditions with no differences in between them. MTN showed a significant higher Neutrophil concentration $\left(4.9 \pm 1.810^{9} / \mathrm{L}\right)$ at $1 \mathrm{hr}$ compared to CHO $\left(3.9 \pm 1.510^{9} / \mathrm{L}\right)$ but not to PL $\left(4.5 \pm 1.610^{9} / \mathrm{L}\right)$.

\section{Conclusion}

Ingesting a multi-ingredient supplement during and immediately after a $90 \mathrm{~min}$ intermittent repeated sprint test resulted in no effects on performance and higher Neutrophil counts. However, fatigue perception and the accumulation of some muscle damage markers $(\mathrm{Mb})$ could be attenuated.

\footnotetext{
Authors' details

${ }^{1}$ Centre for Sport Science and Human Performance, School of Science, University of Greenwich, United Kingdom. ${ }^{2}$ Fundamentals of Motricity and Sports Training Department, School of Sports Sciences, European University of Madrid, Madrid, Spain. ${ }^{3}$ Faculty of Science Engineering and Computing,
} 
Published: 1 December 2014

doi:10.1186/1550-2783-11-S1-P8

Cite this article as: Naclerio et al:: Effect of a multi-ingredient supplement on intermittent sprint performance, fatigue perception,

muscle damage and immunosuppression in recreational athletes.

Journal of the International Society of Sports Nutrition 2014 11(Suppl 1):P8.

Submit your next manuscript to BioMed Central and take full advantage of:

- Convenient online submission

- Thorough peer review

- No space constraints or color figure charges

- Immediate publication on acceptance

- Inclusion in PubMed, CAS, Scopus and Google Scholar

- Research which is freely available for redistribution

Submit your manuscript at www.biomedcentral.com/submit 